\title{
A NEW DINOSAUR, STEGOSAURUS MARSHI, FROM THE LOWER CRETACEOUS OF SOUTH DAKOTA.
}

\author{
By Frederic A. Lucas,
}

Curator, Division of Comparative Anatomy, in charge of Section of Vertebrate Fossils.

The name Stegosaurus marshi is proposed for a new species of Stegosaur represented by a number of plates, spines, and portions of the nuchal and gular armature, as well as by some vertebræ and bones of the limbs, obtained by Mr. N. H. Darton in South Dakota from beds considered by him to be of Lower Cretaceous age.

This material, which is in the U.S. National Museum and is the type of the species, is numbered 4752 in the catalogue of fossil vertebrates. It was found associated with remains of another dinosaur of moderate size, probably related to Camptosaurus. The species is characterized by the general massive appearance of the plates and spines, the comparatively large extent of their basal surfaces, their abrupt taper and sharp edges. In these respects they are quite different from the corresponding portions of any other Stegosaur yet discovered, and coming as they do from the highest horizon in which remains of Stegosaurs have been found they may be considered as representing the latest developments in the dermal armature of this remarkable group of dinosaurs.

A dermal spine, found by Mr. J. B. Hatcher, in conjunction with remains of Triceratops, and regarded at the time as belonging to that genus, may very likely have come from the species under consideration.

A spine, shown on Plate XXIII, presumably from near the posterior end of the caudal series, has a long and comparatively wide basal portion and then tapers rapidly to a spike-like form.

A plate, shown on Plate XXIV, apparently from the caudal series, somewhat in advance of the spine just described, is triangular in section, slightly rounded on one surface, while on the other it tapers abruptly from the base with a concave curve. 
Another plate, probably from the dorsal series, is much more compressed than either of the two already noted, and seen in profile has the form of a rather narrow, high triangle.

None of the large, thin, flattened plates, so characteristic of Stegosaurs hitherto described, are present, and while the material available is too scanty to warrant any positive assertion regarding them, yet it seems probable that in the species under consideration all the plates were small and heavy.

The nuchal armor consists of small, thick, irregularly quadrilateral plates, slightly keeled, and these, save for their smoothness, are suggestive of the nuchal and dorsal plates of crocodiles.

The throat was protected by rounded ossicles varying from 3 to 25 $\mathrm{mm}$. in diameter, and many of these are present on the slab containing the nuchal plates. It is entirely probable that this species represents a distinct genus of Stegosaurs; but in the absence of material on which to base a generic diagnosis it seems best not to bestow upon it a new generic name.

This specimen was recognized by the late Prof. O. C. Marsh as representing a new form and, as it was almost the last specimen to be studied by him, it seems particularly appropriate to name the species in honor of one who did so much to make the Stegosaurs known.

The following are the measurements of the spine and plates described: Caudal spine, shown on Plate XXIII, $370 \mathrm{~mm}$. high and 252 in anteroposterior diameter; caudal plate, shown on Plate XXIV, $304 \mathrm{~mm}$. high and 155 in antero-posterior diameter; width of articular face $148 \mathrm{~mm}$; dorsal plate $380 \mathrm{~mm}$. in greatest height, and 198 in antero-posterior diameter. 


\section{$2 \mathrm{BHL}$ Biodiversity Heritage Library}

Lucas, Frederic A. 1901. "A new dinosaur, Stegosaurus marshi, from the Lower Cretaceous of South Dakota." Proceedings of the United States National Museum 23(1224), 591-592. https://doi.org/10.5479/si.00963801.23-1224.591.

View This Item Online: https://www.biodiversitylibrary.org/item/32360

DOI: https://doi.org/10.5479/si.00963801.23-1224.591

Permalink: https://www.biodiversitylibrary.org/partpdf/26645

\section{Holding Institution}

Smithsonian Libraries

\section{Sponsored by}

Smithsonian

\section{Copyright \& Reuse}

Copyright Status: NOT_IN_COPYRIGHT

This document was created from content at the Biodiversity Heritage Library, the world's largest open access digital library for biodiversity literature and archives. Visit BHL at https://www.biodiversitylibrary.org. 